\title{
Analisis Pengaruh Good Corporate Governance terhadap Manajemen Laba pada Perusahaan Perbankan yang terdaftar di BEI
}

\author{
Viola Syukrina E Janrosl \\ UniversitasPuteraBatam \\ Viola.myudzz21@gmail.com
}

\author{
Joyce Lim \\ UniversitasPuteraBatam \\ Joycelim8989@gmail.com
}

\begin{abstract}
ABSTRAK
Manajemen laba memiliki tujuan yaitu untuk menyeimbangkan berbagai kepentingan yang disebut corporate governance. Kasus manajemen laba telah terjadi pada Bank Bukopin dimana temuan OJK mengenai restated laporan keuangan dengan merevisi laba bersih pada tahun 2016 dari $R p 1,08$ triliun menjadi Rp 183,56 miliar yang mana penurunan terbesar pada bagian pendapatan provisi dan komisi yang merupakan pendapatan dari kartu kredit. Menganalisispengaruh komisaris independen, kepemilikan manajerial, kepemilikan institusional dan komite audit terhadap manajemen laba pada perusahaan perbankan adalah tujuan penelitian ini. Good Corporate Governance sebagai seperangkat peraturan yang mengatur hubungan antar pemegang, pengelola perusahaan, pihak kreditur, pemerintah, karyawan, serta para pemegang kepentingan internal dan eksternal lainnya yang berkaitan dengan hakhak dan kewajiban mereka atau dengan kata lain suatu sistem yang mengendalikan perusahaan. Good corporate governance dalam penelitian ini menggunakan Komisaris Independen, Kepemilikan Manajerial, Kepemilikan Institusional dan Komite Audit. Pada riset ini data penelitian yaitu perusahan perbankan terdaftar di BEI tahun 2016-2018. Sampe1 penelitian berjumlah 43 perusahaan. Hasil penelitian ini Komisaris Independen berpengaruh signifikan terhadap manajemen laba. Kepemilikan Manajerial berpengaruh signifikan terhadap manajemen laba. Kepemilikan Institusional tidak berpengaruh signifikan terhadap manajemen laba. Komite audit berpengaruh signifikan terhadap manajemen laba. Komisaris independen, kepemilikan manajerial, kepemilikan institusional dan komite audit secara simultan berpengaruh signifikan terhadap manajemen laba.
\end{abstract}

Kata kunci: komisaris independen, kepemilikan manajerial, kepemilikan institusional,komite audit, manajemen laba 


\section{PENDAHULUAN}

Pada umumnya, sebuah perusahaan didirikan dengan maksud untuk memperoleh laba semaksimal mungkin dan mempertahankan kelangsungan hidup perusahaan di masa mendatang. Agar maksud tersebut terwujud, perusahaan harus mampu memaksimalkan pemberdayaan sumber daya yang ada dengan cara yang tepat dan efisisen (Setia \& Nopiana, 2012).

Penyajian terstruktur yang menunjukkan kondisi finansial dan kinerja keuangan suatu perusahaan yang memberikan informasi mengenai kondisi keuangan, prestasi kerja manajemen keuangan dan pengelolaan kas perusahaan yang dapat membantu pengguna laporan untuk membuat keputusan dalam suatu peluang bisnis disebut dengan laporan keuangan. Laporan keuangan dapat digunakan sebagai bukti pertanggung jawaban manajemen atas penggunaan sumber daya perusahaan (Diana \& Setiawati, 2017).

Laporan keuangan tersebut penting bagi para pengguna eksternal terutama karena kelompok ini berada dalam kondisi yang paling besar ketidakpastiannya. Asimetri antara manajemen dengan pemilik dapat memberikan kesempatan kepada manajer untuk melakukan manajemen laba (earnings management) dalam rangka menyesatkan pemilik mengenai kinerja ekonomi perusahaan (Saraya, 2011).

Kasus manajemen laba pada Bank Bukopin dimana temuan OJK mengenai restated laporan keuangan dengan merevisi laba bersih pada tahun 2016 dari Rp 1,08 triliun menjadi Rp 183,56 miliar yang mana penurunan terbesar pada bagian pendapatan provisi dan komisi yang merupakan pendapatan dari kartu kredit. Pendapatan ini awalnya $\mathrm{Rp}$ 1,06 triliun menjadi Rp 317,88 miliar. Berdasarkan kasus ini diduga manipulasi data kartu kredit. Inisiden modifikasi data kartu kredit ini memaksa Bukopin menyiapkan action plan untuk menyehatkan CAR ke level $14 \%$. Langkah yang dilakukan adalah rights issue dengan menerbitkan saham baru $30 \%$ dan divestasi $40 \%$ saham BSB (Sugianto, 2018).

Manajemen laba memiliki tujuan yaitu untuk menyeimbangkan berbagai kepentingan yang disebut corporate governance. Corporate governance adalah pengajuan suatu konsep yang dilakukan demi peningkatan kinerja perusahaan dengan melakukan pengontrolan kinerja manajemen dan menjamin akuntabilitas manajemen terhadap pihak - pihak berkepentingan (stakeholder) berdasarkan prinsipprinsip peraturan yang telah ditentukan. Manajemen laba biasanya dilakukan oleh manajer pada proses pelaporan keuangan suatu entitas dengan harapan memperoleh umpan balik berupa manfaat dari tindakan atau dampak positif yang dihasilkan dari apa yang dilakukannya (Indriastuti, 2012).

Kita dapat mengurangi tindakan manajer yang melakukan manipulasi laba dengan menerapkan mekanisme good corporate governance. Good corporate governance adalah serangkaian cara kerja yang dilakukan suatu organisasi yang bertujuan untuk meminimalisir munculnya masalah 
asimetri informasi (perbedaan informasi yang diperoleh antar kedua pihak terlibat) yang dapat mengakibatkan dilakukannya manipulasi laba (Guna \& Herawaty, 2010).

Kasus PT Indofarma Tbk dimana laporan keuangan akhir tahun terdapat peningkatan pada penjualan dan diawal tahun penjualan menurun drastic dengan alasan return penjualan besar-besaran ternyata setelah diperiksa pihak BPKP (Badan Pemeriksa Keuangan Pembangunan) terjadi kecurangan pada laporan keuangan PT Indofarma Tbk. Kasus ini mengakibatkan harga saham perusahaan turun dan kesulitan pembiayaan (Rhenald, 2016). Beberapa kasus skandal pelaporan keuangan menimbulkan pertanyaan bagaimana penerapan good corporate governance dalam sebuah perusahaan untuk meminimalkan manajemen laba.

Good Corporate Governance sebagai seperangkat peraturan yang mengatur hubungan antar pemegang, pengelola perusahaan, pihak kreditur, pemerintah, karyawan, serta para pemegang kepentingan internal dan eksternal lainnya yang berkaitan dengan hak-hak dan kewajiban mereka atau dengan kata lain suatu sistem yang mengendalikan perusahaan. Good corporate governance dalam penelitian ini menggunakan Komisaris Independen, Kepemilikan Manajerial, Kepemilikan Institusional dan Komite Audit.

Komite audit sangat berperan dalam hal menjaga kredibilitas penyusunan laporan keuangan serta menjaga terwujudnya sistem pengontrolan perusahaan yang tepat serta dilaksanakannya good corporate governance. Perusahaan dapat menjadi lebih baik dan terhindar dari konflik keagenan jika komite audit berjalan secara efektif (Ningsaptiti, 2010).

\section{LANDASAN TEORI}

\subsection{Manajemen Laba}

Manajemen laba merupakan setiap tindakan yang dapat mempengaruhi angka laba yang dilaporkan dan dalam proses pelaporan keuangan eksternal yang dilakukan manajemen untuk kepentingan pribadinya yaitu dengan maksud menguntungkan diri manajer perusahaan sendiri (Guna \& Herawaty, 2010).

Fenomena manajemen laba sangat sukar dihindari karena dampak dari penggunaan dasar akrual dalam penyusunan laporan keuangan. Dampak dari penggunaan akuntansi yang merupakan alat komunikasi antara pihak-pihak berkepentingan dan kelemahan internal perusahaan yang ada pada akuntansi sehingga berdampak judgement mengakibatkan manajemen laba terjadi (Guna \& Herawaty, 2010).

Dengan proksi discretionary accrual dapat mengukur manajemen laba. Biasanya pengukuran dengan proksi ini digunakan untuk menilai adanya tindakan manajemen laba yang hanya memihak pada kepentingan manajemen sendiri. Laba yang bebas dari tindakan rekayasa dan manipulasi adalah laba yang berkualitas tinggi. Dalam pengukuran manajemen laba melalui discretionary accrual digunakan suatu model yang disebut 
dengan model Jones (Abdillah \& Susilawati, 2014).

Discretionary accruals yang digunakan sebagai proksi manajemen labadalam penelitian ini merupakan modifikasi cross sectional dari model Jones, yang dapat mendeteksi manajemen laba secara konsisten (Abdillah \& Susilawati, 2014). Rumus yang digunakan untuk menentukan nilai total accruals untuk sampel perusahaan yang terpilih dengan pendekatan cash flow adalah sebagai berikut:

$$
\mathrm{TA}_{\mathrm{it}} / \mathrm{A}_{\mathrm{it}-1}=\left(\mathrm{NI}_{\mathrm{t}}-\mathrm{OCF}_{\mathrm{t}}\right) / \mathrm{A}_{\mathrm{it}-1}
$$

Keterangan:

$\mathrm{TA}_{\mathrm{it}}$ : Total Accruals pada periode $\mathrm{t}$

$\mathrm{A}_{\mathrm{it-1}}$ : Total aset untuk sampel perusahaan i pada akhir periode $\mathrm{t}-1$ $\mathrm{NI}_{\mathrm{t}}$ : Laba bersih operasi (net operating income) periode $\mathrm{t}$

$\mathrm{OCF}_{\mathrm{t}}$ : Aliran kas dari aktivitas operasi (operating cash flow) pada periode t.

\subsection{Good Corporate Governance}

Good corporate governance merupakan struktur bagi stakeholder, pemegang saham, komisaris dan manajer menyusun tujuan perusahaan dan sebagai suatu media perantara untuk mencapai tujuan dan mengawasi kinerja perusahaan. Hal ini dikemukakan oleh Cadbury Committee "A set of rules that define a relationship between shareholders, manager, creditor, the government, employees and other internal and external stakeholder in respect to their and responsibilities" (Banjarnahor, 2014).
Penilaian faktor tata kelola merupakan penilaian terhadap kualitas manajemen bank atas penerapan prinsip tata kelola yang baik. Prinsip tata kelola yang baik dan fokus penilaian terhadap penerapan prinsip tata kelola yang baik yang berpedoman melalui ketentuan Otoritas Jasa Keuangan dengan memperhatikan karakteristik dan kompleksitas usaha bank(Indonesia, 2014).

World Bank mendefinisikan good corporate governance adalah sekumpulan hukum, peraturan, dan suatu pedoman yang wajib dipenuhi, dapat membantu kinerja sumbersumber entitas agar berfungsi secara efisien dan dapat menghasilkan nilai ekonomi jangka panjang yang berkesinambungan bagi pemegang saham maupun masyarakat secara keseluruhan. Dapatdiartikan Good corporate governance sebagai seperangkat sistem yang mengatur serta mengendalikan perusahaan untuk menciptakan nilai tambah bagi pihak yang berkepentingan. Hal ini disebabkan karena good corporate governance dapat mendorong terbentuknya pola kerja manajemen yang Bersih, Transparan, dan Profesional (Banjarnahor, 2014).

Terdapat beberapa mekanisme corporate governance yang digunakan untuk menganalisis manajemen laba, diantaranya sebagai berikut:

1. Komisaris Independen (KID)

Sebuah badan dalam perusahaan yang beranggotakan dewan komisaris independen yang berasal dari luar perusahaan yang bertugas menilai kinerja perusahaan disebut Komisaris Indenpenden (Widaryanti \& Sukanto, 
2014). Komisaris independen dapat dirumuskan sebagai berikut:

$\mathrm{KID}=$ Jumlah Komisaris Independen

Total Dewan Komisaris

\section{Kepemilikan Manajerial (KPM)} Yang dimaksud dengan kepemilikan manajerial adalah persentase saham yang dimiliki oleh manajemen yang secara aktif ikut dalam pengambilan keputusan suatu perusahaan. Kepemilikan manajerial dapat dirumuskan sebagai berikut:

$$
\text { KPM }=\frac{\text { Jumlah Saham Manajemen }}{\text { Total SahamBeredar }}
$$

3. Kepemilikan Institusional

Kepemilikan institusional merupakan kepemilikan saham perusahaan yang dimiliki oleh institusi seperti perusahaan asuransi, bank, perusahaan investasi dan kepemilikan institusi lain (Anggriani, 2017). Kepemilikan Institusional dapat dirumuskan sebagai berikut:

\section{KPI =Jumlah Saham Institusional Total Saham Yang Beredar}

\section{Komite Audit}

Komite yang dibentuk oleh dewan direksi yang bertugas melaksanakan pengawasan independen dan audit ekstern perusahaan disebut Komite Audit (Savitri, 2010). Komite audit dalam penelitian ini diproksikan dengan dummy variable nilai 1 jika ada komite audit dan 0 jika tidak ada komite audit.

\subsection{Hipotesis Penelitian}

Dari landasan teori dan penelitian terdahulu maka hipotesis dari penelitian ini adalah sebagai berikut:

1. Komisaris independen berpengaruh terhadap manajemen laba pada perusahaan perbankan.

2. Kepemilikan manajerial berpengaruh terhadap manajemen laba pada perusahaan perbankan.

3. Komisaris institusional berpengaruh terhadap manajemen laba pada perusahaan perbankan.

4. Komite auditterhadap berpengaruh manajemen laba pada perusahaan perbankan.

5. Komisaris independen, kepemilikan manajerial, kepemilikan institusional, dan komite audit berpengaruh terhadap manajemen laba pada perusahaan perbankan.

\section{METODE PENELITIAN}

\subsection{Desain Penelitian}

Penelitian ini adalah penelitian kualititatif (conclusive research design). Data diolah dengan bantuan software SPSS 21.0. Kerangka kerja atau alur yang digunakan dalam suatu penelitian. Digunakan dalam penelitian ini adalah desain penelitian eksploratif dan deskriptif. Dimana Penelitian eksploratif bertujuan untuk menyelidiki suatu masalah atau situasi untuk mendapatkan pengetahuan dan pemahaman yang baik. Sedangkan penelitian deskriptif memiliki pertanyaan jelas mengenai permasalahan yang dihadapi, hipotesis dan informasi detail yang dibutuhkan. 


\subsection{Populasi dan Sampel}

Populasi yang digunakan dalam penelitian adalah perusahaan perbankan terdaftar di BEI tahun 2016-2018. Sampel penelitian berjumlah 43 perusahaan.

\subsection{Variabel Penelitian}

\section{Manajemen Laba}

Diukur dengan proksi discretionary accrual. Discretionary accruals yang digunakan sebagai proksi manajemen labadalam penelitian ini merupakan modifikasi cross sectional dari model Jones, yang dapat mendeteksi manajemen laba secara konsisten (Abdillah \& Susilawati, 2014). Rumus yang digunakan untuk menentukan nilai total accruals untuk sampel perusahaan yang terpilih dengan pendekatan cash flow adalah sebagai berikut:

$$
\mathrm{TA}_{\mathrm{it}} / \mathrm{A}_{\mathrm{it}-1}=\left(\mathrm{NI}_{\mathrm{t}}-\mathrm{OCF}_{\mathrm{t}}\right) / \mathrm{A}_{\mathrm{it}-1}
$$

Keterangan:

$\mathrm{TA}_{\mathrm{it}}$ : Total Accruals pada periode $\mathrm{t}$

$\mathrm{A}_{\mathrm{it}-1}$ : Total aset untuk sampel perusahaan i pada akhir periode $\mathrm{t}-1$

$\mathrm{NI}_{\mathrm{t}}$ : Laba bersih operasi (net operating income) periode $\mathrm{t}$

$\mathrm{OCF}_{\mathrm{t}}$ : Aliran kas dari aktivitas operasi (operating cash flow) pada periode t.

\section{Komisaris independen}

Sebuah badan dalam perusahaan beranggotakan dewan komisaris independen berasal dari luar perusahaan bertugas menilai kinerja perusahaan (Widaryanti \& Sukanto, 2014). Komisaris independen dapat dirumuskan sebagai berikut:
$\mathrm{KID}=\frac{\text { Jumlah Komisaris Independen }}{\text { Total Dewan Komisaris }}$

3. Kepemilikan Manajerial (KPM)

Persentase saham yang dimiliki oleh manajemen secara aktif ikut dalam pengambilan keputusan suatu perusahaan. Kepemilikan manajerial dapat dirumuskan sebagai berikut:

$\mathrm{KPM}=$ Jumlah Saham Manajemen Total Saham Beredar

4. Kepemilikan Institusional Merupakan kepemilikan saham perusahaan yang dimiliki oleh institusi seperti perusahaan asuransi, bank, perusahaan investasi dan kepemilikan institusi lain (Anggriani, 2017). Kepemilikan Institusional dapat dirumuskan sebagai berikut:

KPI = Jumlah Saham Institusional Total Saham Yang Beredar

\section{Komite Audit}

Merupakan komite yang dibentuk oleh dewan direksi bertugas melaksanakan pengawasan independendan audit ekstern perusahaan (Savitri, 2010). Komite audit dalam penelitian ini diproksikan dengan dummy variable nilai 1 jika ada komite audit dan 0 jika tidak ada komite audit.

\subsection{Teknik Pengumpulan Data}

Jenis data yang digunakan pada penelitian ini yaitu data sekunder yaitu berupa laporan keuangan tahunan perusahaan perbankan yang menyajikan informasi lengkap mengenai data komisaris independen, kepemilikan manajerial, kepemilikan institusional, komite audit dan 
manajemen laba. Data untuk penelitian ini diperoleh dari laporan keuangan tahunan perusahaan publik yang terdaftar di Bursa Efek Indonesia (BEI). Data tersebut meliputi laporan keuangan perusahaan periode 20162018.

\section{HASIL PENELITIAN DAN PEMBAHASAN}

Hasil penelitian merupakan ringkasan dari informasi yang diperoleh dari data dan disajikan dari bentuk analisis deskriptif, uji asumsi klasik dan uji regresi linear berganda.

\subsection{Statisik Deskriptif}

Statistik deskriptif digunakan untuk mendeskripsikan dan memberikan gambaran tentang distribusi frekuensi variabel-variabel dalam penelitian ini, nilai maksimum, minimum, rata-rata (mean) dan standar deviasi. Berdasarkan data olahan SPSS yang meliputi komisaris independen, kepemilikan manajerial, kepemilikan institusional, komite audit dan manajemen laba maka akan dapat diketahui nilai maksimum, nilai minimum, rata-rata (mean) dan standar deviasi dari setiap variabel (Ghozali, 2013).

\begin{tabular}{lrrrrr}
\multicolumn{7}{c}{ Tabel 1 } \\
\hline \multicolumn{5}{c}{ Descriptive Statistics } \\
\hline Komisaris & 6 & .0 & 1.00 & .6219 & .24964 \\
Independe & 4 & 0 & & & \\
$\mathrm{n}$ & & & & & \\
Kepemilik & 6 & .9 & 433.7 & 41.458 & 115.476 \\
an & 4 & 6 & 8 & 1 & 26 \\
Manejerial & & & & & \\
Kepemilik & 6 & .0 & 26.99 & 3.6122 & 4.46837 \\
an & 4 & 0 & & & \\
Institusion & & & & & \\
al & & & & & \\
Komite & 6 & .0 & 1.00 & .9531 & .21304 \\
Audit & 4 & 0 & & & \\
\hline
\end{tabular}

Berdasarkan tabel 1 dapat dilihat nilai minimum variabel komisaris independen yaitu0.00,nilai maksimum 1.00 , nilai rata-rata 0,6219 dan standar deviasinya 0,24964. Komisaris independen menunjukkan besarnya rasio keberadaan komisaris independen menunjukkan rata-rata sebesar $24,96 \%$ yang berarti bahwa secara rata-rata keberadaan komisaris independen dalam perusahaan sebesar 24,96\% dari seluruh dewan komisaris. Keberadaan komisaris independen paling rendah adalah 0.00 sedangkan paling tinggi mencapai 1.00, Komisaris independen memiliki nilai standar deviasi sebesar 0,24964 dengan demikian batas penyimpangan komisaris independen adalah 0,24964.

Nilai minimum kepemilikan manajerial yaitu0.96,nilai maksimum 433.78, nilai rata-rata 41.4581 dan standar deviasinya 115.47626. Kepemilikan manajerial menunjukkan besarnya persentase saham yang dimiliki oleh manajerial menunjukkan rata-rata sebesar 41.4581. Hal ini berarti bahwa rata-rata porsi kepemilikan saham yang dimiliki oleh manajerial perusahaan adalah sebesar $41.4581 \%$ dari seluruh saham yang beredar. Kepemilikan saham manajerial paling rendah adalah 0.96 sedangkan yang paling banyak mencapai 433.78. Kepemilikan manajerial memiliki nilai standar deviasi sebesar 115.47626 dengan demikian batas penyimpangan kepemilikan manajerial adalah $115.47626 \%$.

Nilai minimum kepemilikan institusional yaitu0.00,nilai maksimum 26.99, nilai rata-rata 3.6122 dan standar deviasinya 
4.46837. Kepemilikan saham institusional menunjukkan besarnya persentase saham yang dimiliki oleh institusi di luar perusahaan menunjukkan rata-rata sebesar 3.6122 $\%$. Hal ini berarti bahwa rata-rata porsi kepemilikan saham yang dimiliki oleh institusi lain dalam perusahaan adalah sebesar $3.6122 \%$ dari seluruh saham yang beredar. Kepemilikan saham institusional paling rendah adalah 0.00 sedangkan yang paling banyak mencapai 26,99\%. Kepemilikan instistusional memiliki nilai standar deviasi sebesar 4.46837 dengan demikian batas penyimpangan kepemilikan instistusional adalah $4.46837 \%$.

Nilai minimum komite audit yaitu0.00,nilai maksimum 1.00 , nilai rata-rata 0.0580 dan standar deviasinya 0.21304. Komite Audit menunjukkan besarnya persentase keberadaan komite audit perusahaan menunjukkan rata-rata sebesar 95.31 $\%$. Komite audit paling rendah adalah 0.00 sedangkan yang paling banyak mencapai 1.00. Komite Audit memiliki nilai standar deviasi sebesar 0.21304 .

Nilai minimum manajemen laba yaitu0.00,nilai maksimum 0.16 , nilai rata-rata 0.7885 dan standar deviasinya 0.04677 . Nilai mean menunjukan nilai discretionary accruals pada perusahaan yang menjadi sampel bernilai positif dengan asumsi bahwa perusahaan sampel memiliki tingkat laba sebesar 0,00 dengan standar deviasi yang juga bernilai positif yaitu sebesar 0.04677 . Hasil tersebut menunjukan bahwa pada periode 2015-2017 perusahaan perbankan di Indonesia yang terdaftar di Bursa Efek Indonesia telah melakukan tindak manajemen laba engan pola memaksimalkan labanya namun dengan kapasitas yang sangat kecil.

\subsection{Hasil Uji Asumsi Klasik 4.2.1 Hasil Uji Normalitas}

Uji normalitas berguna untuk melihat apakah data telah terdistribusi normal atau tidak. Pengujian normalitas dalam penelitian ini menggunakan, uji non-parametrik Kolmogorov-Smirnov (K-S).Uji Kolmogrov-Smirnov, pedoman yang digunakan dalam pengambilan keputusan dalam uji ini adalah:

a. Menggunakan nilai probability sig (2tailed) $>\alpha ;$ sig $>0,05$ maka distribusi data normal

b. Menggunakan nilai probability sig (2tailed) $<\alpha$; sig $<0,05$ maka distribusi data tidak normal.

Tabel 2. Uji Kolmogorov-Smirnov One-Sample Kolmogorov-Smirnov Test

\begin{tabular}{|c|c|c|}
\hline $\mathrm{N}$ & & 64 \\
\hline Normal & Mean & .0000000 \\
\hline Parameters ${ }^{\mathrm{a}, \mathrm{b}}$ & $\begin{array}{l}\text { Std. } \\
\text { Deviation }\end{array}$ & .03560052 \\
\hline Most Extreme & Absolute & .157 \\
\hline Differences & $\begin{array}{l}\text { Positive } \\
\text { Negative }\end{array}$ & $\begin{array}{l}.157 \\
-.109\end{array}$ \\
\hline $\begin{array}{l}\text { Kolmogorov-Smi } \\
\text { Asymp. Sig. (2-ta }\end{array}$ & $\begin{array}{l}\operatorname{lov} \mathrm{Z} \\
\text { ed) }\end{array}$ & $\begin{array}{l}1.253 \\
.087\end{array}$ \\
\hline
\end{tabular}

Menganalisis nilai kolmogorovsmirnov di atas bisa diambil kesimpulan bahwa, data memiliki distribusi normal karena nilai kolmogorov-smirnov memiliki tingkat signifikan0,087 >0,05.

\subsubsection{Hasil Uji Multikolinieritas}


Uji ini akan membahas ada tidaknya multikolinieritas atau terjadinya korelasi diantara sesama variabel bebas. Model regresi yang baik tentunya tidak ada multikolinier atau adanya korelasi diantara variable bebas. Berdasarkan table output yang telah diolah oleh SPSS 21 yang melibatkan variable dependent maka dihasilkan table colinierity sebagai berikut:

\begin{tabular}{|c|c|c|}
\hline Model & Tolerance & VIF \\
\hline 1 (Constant) & .606 & 1.651 \\
\hline \begin{tabular}{l|l} 
KOMISARIS \\
INDEPENDEN
\end{tabular} & .767 & 1.304 \\
\hline $\begin{array}{l}\text { KEPEMILIKAN } \\
\text { MANAJERIAL }\end{array}$ & .821 & 1.218 \\
\hline $\begin{array}{l}\text { KEPEMILIKAN } \\
\text { INSTITUSIONAL }\end{array}$ & .826 & 1.210 \\
\hline
\end{tabular}

Berdasarkan hasil perhitungan diatas tampak bahwa VIF dari masingmasing variabel yaitu $\mathrm{X}_{1}=1.651, \mathrm{X}_{2}=$ $1.304, \quad X_{3}=1.218$ dan $X_{4}=1.210$ berada di bawah angka 10 . Dengan demikian bahwa model tersebut tidak memiliki gejala multikolinieritas.

\subsection{Hasil Uji Pengaruh}

\subsubsection{Hasil Uji t (Persial)}

Digunakan untuk mengetahui pengaruh variabel independen atau bebas $(\mathrm{X})$ terhadap variabel dependen atau terikat (Y). Hipotesis dalam pengujian ini, sebagai berikut:

$\mathbf{H}_{1}=$ Variabel X1 berpengaruh terhadap variabel $Y$.

$\mathbf{H}_{2}=$ Variabel $\mathrm{X} 2$ berpengaruh terhadap variabel $\mathrm{Y}$

Kaidah pengambilan keputusan dalam pengujian ini adalah:
1. Jika $\mathbf{t}$ hitung $>\mathbf{t}$ tabel dan nilai Signifikan $<0,05$, maka $\mathbf{H}_{1}$ diterima, jadi variabel independen

2. (X) berpengaruh signifikan terhadap variabel dependen $(\mathrm{Y})$.

3. Jika $\mathbf{t}$ hitung $<\mathbf{t}$ tabel dan nilai Signifikan $>0,05$, maka $\mathbf{H}_{2}$ ditolak, jadi variabel independen (X) tidak berpengaruh signifikan terhadap variabel dependen (Y).

\begin{tabular}{|c|c|c|c|c|c|}
\hline \multicolumn{6}{|c|}{$\begin{array}{l}\text { Tabel 5. Uji T } \\
\text { Coefficients }^{\mathrm{a}}\end{array}$} \\
\hline Model & \multicolumn{2}{|c|}{$\begin{array}{l}\text { Unstandardize } \\
\text { d Coefficients }\end{array}$} & $\begin{array}{l}\text { Standa } \\
\text { rdized } \\
\text { Coeffi } \\
\text { cients }\end{array}$ & $\mathrm{T}$ & $\begin{array}{l}\mathrm{Si} \\
\mathrm{g} .\end{array}$ \\
\hline $\begin{array}{l}1 \\
\text { (Constant) }\end{array}$ & $\begin{array}{l}.20 \\
1\end{array}$ & $\begin{array}{l}.03 \\
2\end{array}$ & & $\begin{array}{l}6.2 \\
54\end{array}$ & $\begin{array}{l}.0 \\
00\end{array}$ \\
\hline \begin{tabular}{|l} 
Komisa \\
ris \\
Indepen \\
den
\end{tabular} & $\begin{array}{l}- \\
.15 \\
0\end{array}$ & $\begin{array}{l}.02 \\
4\end{array}$ & -.803 & $\begin{array}{l}- \\
6.3 \\
07\end{array}$ & $\begin{array}{l}.0 \\
00\end{array}$ \\
\hline $\begin{array}{l}\text { Kepemi } \\
\text { likan } \\
\text { Manajer } \\
\text { ial }\end{array}$ & $\begin{array}{l}.00 \\
0\end{array}$ & $\begin{array}{l}.00 \\
0\end{array}$ & .424 & $\begin{array}{l}3.7 \\
49\end{array}$ & $\begin{array}{l}.0 \\
00\end{array}$ \\
\hline $\begin{array}{l}\text { Kepemi } \\
\text { likan } \\
\text { Insitusi } \\
\text { onal }\end{array}$ & $\begin{array}{l}.00 \\
0\end{array}$ & $\begin{array}{l}.00 \\
1\end{array}$ & -.079 & $\begin{array}{l}- \\
.72 \\
2\end{array}$ & $\begin{array}{l}.4 \\
73\end{array}$ \\
\hline
\end{tabular}

Dari tabel 5 diatas dapat dilihat hasil uji t hitung, sehingga dibandingkan dengan $\mathrm{t}$ table. Hasil perhitungan untuk nilai signifikan $0.000<0,05$ dan $\mathrm{t}$ hitung $6.307>$ 2.001. Dapat disimpulkan bahwa komisaris independen berpengaruh signifikan terhadap manajemen laba.

Hasil perhitungan untuk nilai signifikan $0.000<0,05$ dan $t$ hitung $3.749>2.001$. Dapat disimpulkan kepemilikan manajerial berpengaruh signifikan terhadap terhadap manajemen laba.

Hasil perhitungan untuk nilai signifikan $0.473>0,05$ dan $\mathrm{t}$ hitung $0.722<2.001$. Dapat disimpulkan 
kepemilikan institusional tidak berpengaruh signifikan terhadap manajemen laba

Hasil perhitungan untuk nilai signifikan $0.023<0,05$ dan $t$ hitung $2.335>2.001$. Dapat disimpulkan komite audit berpengaruh signifikan terhadap manajemen laba.

\subsubsection{Hasil Uji F (simultan)}

Pengujian ini dilakukan untuk mengetahui apakah semua variabel independen $\left(\mathrm{X}_{1}, \mathrm{X}_{2}, \mathrm{X}_{3}\right.$ dan $\left.\mathrm{X}_{4}\right)$ yang dimasukkan dalam model memiliki pengaruh secara bersama-sama terhadap variabel dependen.

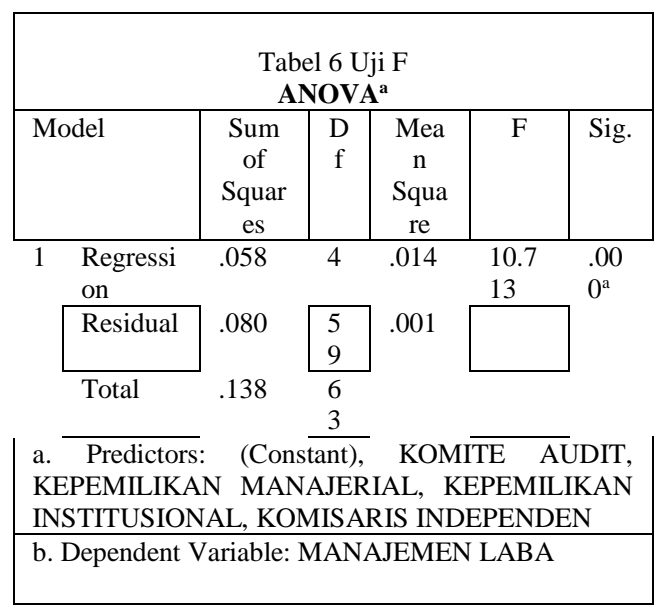

Berdasarkan tabel perhitungan di atas diperoleh nilai Fhitung dibandingkan dengan Ftabel $10.713>$ 2,53 dan nilai signifikan $0,000<0,05$ yang menunjukkan secara simultan komite audit, kepemilikan manajerial, komisaris independen dan kepemilikan institusional berpengaruh secara signifikan terhadap manajemen laba.

Menurut Wibowo (2012: 135) analisis ini digunakan dalam hubungan untuk mengetahui jumlah atau persentase sumbangan pengaruh variabel bebas dalam model regresi yang secara serentak atau bersamasama memberikan pengaruh terhadap variabel bebas. Hasil nilai $\mathrm{R}$ dapat dilihat ditabel dibawah ini:

\begin{tabular}{|c|c|c|c|c|}
\hline \multicolumn{5}{|c|}{$\begin{array}{c}\text { Tabel 7Uji R Square } \\
\text { Model Summary }\end{array}$} \\
\hline $\begin{array}{l}\text { Mod } \\
\text { el }\end{array}$ & $\mathrm{R}$ & $\begin{array}{c}\mathrm{R} \\
\text { Squar } \\
\mathrm{e}\end{array}$ & $\begin{array}{c}\text { Adjuste } \\
\text { d R } \\
\text { Square }\end{array}$ & $\begin{array}{l}\text { Std. } \\
\text { Error } \\
\text { of the } \\
\text { Estimat } \\
\quad \mathrm{e}\end{array}$ \\
\hline 1 & $\begin{array}{r}.649 \\
\mathrm{a}\end{array}$ & .421 & .381 & .03679 \\
\hline \multicolumn{5}{|c|}{$\begin{array}{l}\text { a. Predictors: (Constant), KOMITE } \\
\text { AUDIT, KEPEMILIKAN } \\
\text { MANAJERIAL, KEPEMILIKAN } \\
\text { INSTITUSIONAL, KOMISARIS } \\
\text { INDEPENDEN }\end{array}$} \\
\hline
\end{tabular}

Berdasarkan hasil perhitungan diperoleh bahwa Adjusted R square = 0,381 dapat disimpulkan bahwa komite audit, kepemilikan manajerial, komisaris independen dan kepemilikan institusional berpengaruh terhadap manajemen laba sebesar $38,1 \%$. Sedangkan sisanya $61,9 \%$ dipengaruhi oleh variabel lain yang tidak diteliti.

\subsection{Pembahasan}

Penelitian ini bertujuan untuk menguji dan menganalisis mekanisme corporate governance terhadap ketepatan waktu pelaporan keuangan pada perusahaan perbankan. Variabel dependen ketepatan waktu pelaporan keuangan. Sampel dalam penelitian ini adalah laporan keuangan perusahaan perbankan yang terdaftar di Bursa 
Efek Indonesia sejumlah 52 sampel. Setelah melakukan analisis deskriptif dan serangkaian uji dari data yang diperoleh, maka pada penjelasan akan dijelaskan ringkasan yang dirangkum dari hasil penelitian, yang pada akhirnya dapat menjawab rumusan masalah dari penelitian dengan membuktikan dari hipotesis-hipotesis yang dirumuskan sebelumnya.

\subsubsection{Pengaruh \\ Independen Manajemen Laba}

Hasil perhitungan untuk nilai signifikan $0.000<0,05$ dan $\mathrm{t}$ hitung $6.307>$ 2.001. Dapat disimpulkan bahwa komisaris independen berpengaruh signifikan terhadap manajemen laba. Hal ini karena dewan komisaris independen tidak sepenuhnya independen dalam menjalankan tugasnya. Semakin tinggi persentase komposisi dewan komisaris independen maka akan semakin meningkatkan terjadinya praktik manajemen laba.

Penelitian ini tidak sejalan dengan penelitian yang dilakukan (Saraya, 2011) hasil penelitiannya komisaris independen tidak berpengaruh terhadap manajemen laba, ukuran dewan komisaris independen berpengaruh terhadap manajemen laba, keberadaan komite audit tidak berpengaruh terhadap manajemen laba, kepemilikan manajerial tidak berpengaruh terhadap manajemen laba, dan kepemilikan institusional berpengaruh terhadap manajemen laba.

\subsubsection{Pengaruh \\ Manajerial \\ Kepemilikan Manajemen Laba}

Hasil perhitungan untuk nilai signifikan $0.000<0,05$. Dapat disimpulkan kepemilikan manajerial berpengaruh signifikan terhadap terhadap manajemen laba. Hal ini mengindikasikana kepemilikan manajerial mampu menjadi mekanisme corporate governance yang dapat mengurangi ketidakselarasan kepentingan antara manajemen dengan pemilik pemegang saham dan pemilik.

Penelitian ini sejalan dengan penelitian yang dilakukan ( $\mathrm{S} \&$ Khoiruddin, 2016) hasil penelitian menunjukkan bahwa kepemilikan institusional, kepemilikan manajerial, ukuran dewan komisaris dan komite audit tidak berpengaruh pada manajemen laba.

\subsubsection{Pengaruh Kepemilikan Institusional Terhadap Manajemen Laba}

Hasil perhitungan untuk nilai signifikan $0.473>0,05$. Dapat disimpulkan kepemilikan institusional tidak berpengaruh signifikan terhadap manajemen laba. Hal terjadi karena kepemilikan institusional adalah pemilik yang lebih memfokuskan pada laba saat ini (current earnings).

Penelitian ini sejalan dengan penelitian yang dilakukan (S \& Khoiruddin, 2016) hasil penelitian menunjukkan bahwa kepemilikan institusional tidak berpengaruh pada manajemen laba pada perusahaan yang masuk dalam JII.

\subsubsection{Pengaruh Komite Audit Terhadap Manajemen Laba \\ Hasil perhitungan untuk nilai signifikan $0.023<0,05$. Dapat}


disimpulkan komite audit berpengaruh signifikan terhadap manajemen laba. Hal ini karena yang menunjukkan efektifnya keberadaan komite audit.

Penelitian ini tidak sejalan dengan penelitian yang dilakukan (S \& Khoiruddin, 2016) hasil penelitian menunjukkan bahwa komite audit tidak berpengaruh pada manajemen laba pada perusahaan yang masuk dalam JII.

\section{SIMPULAN DAN SARAN 5.1 Simpulan}

Berdasarkan hasil penelitian dan pembahasan yang telah diuraikan, maka penulis menarik kesimpulan adalah sebagai berikut komisaris Independen berpengaruh signifikan terhadap manajemen laba. Kepemilikan Manajerial berpengaruh signifikan terhadap manajemen laba. Kepemilikan Institusional tidak berpengaruh signifikan terhadap manajemen laba. Komite audit berpengaruh signifikan terhadap manajemen laba.

Komisaris independen, kepemilikan manajerial, kepemilikan institusional dan komite audit secara simultan berpengaruh signifikan terhadap manajemen laba.

\subsection{Saran}

Berdasarkan hasil penelitian penulis mengusulkan saran-saran yang kiranya bermanfaat bagi pihakpihak yang terkait dalam penelitian yaitu penelitian selanjutnya diharapkan menjadikan objek penelitian selain perusahaan perbankan seperti dilakukan pada sektor manufaktur atau penelitian pada seluruh perusahaan (tidak pada sektor tertentu).

Peneliti selanjutnya diharapkan menambah analisis pada perusahaan di luar perusahaan perbankan serta menambah mekanisme corporate governance lain seperti auditor internal, komposisi dewan direksi dan kepemilikan terkonsentrasi

\section{DAFTAR PUSTAKA}

Abdillah, S. Y., \& Susilawati, R. A. E. (2014). Pengaruh Good Corporate Governance Pada Manajemen Laba, 1-14.

Anggriani, F. (2017). Pengaruh Mekanisme Corporate Governance Dan Kinerja Keuangan Terhadap Financial Reporting Lag. Jurnal Ilmu Dan Riset Akuntansi, 6, 102-120.

Banjarnahor, H. (2014). Dampak Corporate Social Responsubility Dan Good Corporate Governance Terhadap Nilai Perusahaan Sektor Manufaktur Listing Di Bei, 62-76.

Campa, D., \& Minano, M. Del M. C. (2015). Nothe Impact Of SME's Pre- Bankruptcy Financial Distress On Earnings Managements Tools. International Review of Financial Analysis.

Ghozali, I. (2011). Aplikasi Analisis Multivariate Dengan Program IBM SPSS 19. Semarang: Badan Penerbit Universitas Diponegoro.

Guna, W. I., \& Herawaty, A. (2010). Pengaruh Mekanisme Good Corporate Governance , Independensi Auditor, Kualitas Audit Dan Faktor Lainnya Terhadap Manajemen Laba, 
12(1), 53-68.

Indriastuti, M. (2012). Analisis Kualitas Auditor Dan Corporate Governance Terhadap Manajemen Laba, $I v(2)$.

Kumari, P., \& Pattanayak, J. K. (2017). No Titlelinking Earnings Management Practices And Corporate Governance System With The Firms' Financial Performance: A Study Of Indian Commercial Banks. Journal Of Financial Crime, 24(2), 223241.

Mawardi, M. C. (2010). Pengaruh Good Corporate Governance Terhadap Manajemen Laba Pada Industri Perbankan Yang Terdaftar Di Bei, 84.

Ningsaptiti, R. (2010). Analisis Pengaruh Ukuran Perusahaan Dan Mekanisme Corporate Governance Terhadap Manajemen Laba.

Rhenald. (2016). Manajemen Laba Dan Contoh Kasus Yang Ada Di Indonesia.

S, E. R. D., \& Khoiruddin, M. (2016). Pengaruh Good Corporate Governance Terhadap Manajemen Laba Pada Perusahaan Yang Masuk Dalam Jii ( Jakarta Islamic Index ) Tahun 2012-2013, 5(3), 156-166.

Saraya, W. A. (2011). Pengaruh Penerapan Good Corporate Governance Terhadap Manajemen Laba Pada Perusahaan Perbankan Di Bursa Efek Indonesia.

Savitri, R. (2010). Pengaruh Mekanisme Corporate Governance Terhadap Ketepatan Waktu Pelaporan Keuangan.
Jurnal Akuntansi, 1.

Setia, M. D., \& Nopiana, P. R. (2012). Analisis Tingkat Penjualan Dan Persediaan Barang Dagang Terhadap Laba Perusahaan Pada Pt Balam Jaya Sentosa Kota Batam, 103-115.

Sugiyono. (2015). Metode Penelitian Kuantitatif, Kualitatif Dan $R \& D$. Bandung.

Syafa'ah, S. A. (2017). Pengaruh Corporate Governance Terhadap Manajemen Laba Di Industri Perbankan Indonesia Artikel Ilmiah.

Widaryanti, \& Sukanto, E. (2014). Analisis Pengaruh Mekanisme Corporate Governance Terhadap Ketepatan Waktu Corporate Internet Reporting Pada Perusahaan Yang Terdaftar Di BEI. Fokus Ekonomi, 9, 1-14. 